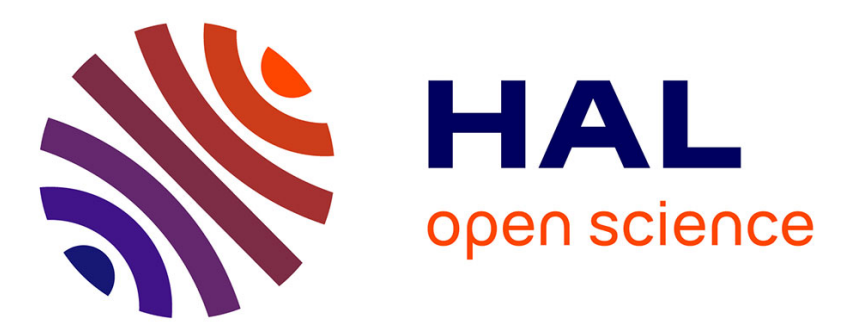

\title{
In vitro response of rat pleural mesothelial cells to talc samples in genotoxicity assays (sister chromatid exchanges and DNA repair)
}

\author{
S Endo-Capron, A. Renier, X Janson, L Kheuang, M C Jaurand
}

\section{To cite this version:}

S Endo-Capron, A. Renier, X Janson, L Kheuang, M C Jaurand. In vitro response of rat pleural mesothelial cells to talc samples in genotoxicity assays (sister chromatid exchanges and DNA repair). Toxicology in Vitro, 1993, 7, pp.7 - 14. 10.1016/0887-2333(93)90107-G . inserm-02449474

HAL Id: inserm-02449474 https://www.hal.inserm.fr/inserm-02449474

Submitted on 22 Jan 2020

HAL is a multi-disciplinary open access archive for the deposit and dissemination of scientific research documents, whether they are published or not. The documents may come from teaching and research institutions in France or abroad, or from public or private research centers.
L'archive ouverte pluridisciplinaire HAL, est destinée au dépôt et à la diffusion de documents scientifiques de niveau recherche, publiés ou non, émanant des établissements d'enseignement et de recherche français ou étrangers, des laboratoires publics ou privés. 


\title{
IN VITRO RESPONSE OF RAT PLEURAL MESOTHELIAL CELLS TO TALC SAMPLES IN GENOTOXICITY ASSAYS (SISTER CHROMATID EXCHANGES AND DNA REPAIR)
}

\author{
S. Endo-Capron*, A. Renier*, X. Janson $\dagger$, L. Kheuang* and M. C. Jaurand* $\ddagger$ \\ *INSERM-U139, Laboratoire de Toxicologie Cellulaire et Moléculaire de l'Environnement, CHU Henri \\ Mondor, 94010 Créteil and †Laboratoire d'Etude des Particules Inhalées, DASS, 11 rue Georges Eastmann, \\ 75013 Paris, France
}

(Received 16 April 1992; revisions received 11 August 1992)

\begin{abstract}
The genotoxicity of three samples of talc has been determined using in vitro cell systems previously developed for testing asbestos fibres. The talc samples used consisted of particles of respirable size in order to test the effect of particles likely to be deposited in the lung. Genotoxicity was tested in cultures of rat pleural mesothelial cells (RPMC) using genotoxicity assays for unscheduled DNA synthesis (UDS) and sister chromatid exchanges (SCEs). The effects were compared with those obtained with negative controls (attapulgite and anatase) and positive controls (chrysotile and crocidolite asbestos). In contrast to asbestos, none of the talc samples, nor the negative controls, induced enhancement of UDS or SCEs in treated cultures in comparison with the untreated cultures.
\end{abstract}

\section{INTRODUCTION}

Talc is a mineral commonly used in various industries including the ceramics, paper, plastics, paints, pharmaceutical and cosmetics industries. It is a magnesium silicate of similar chemical composition to chrysotile asbestos fibres but with a different structure. IARC has evaluated the biological effects of talc (IARC Working Group, 1987); according to their findings the results obtained in previous experiments in vivo and in vitro were inadequate to evaluate the carcinogenicity or genotoxicity of talc because of the limited number of studies. Data from animal studies did not show an excess of pleural sarcomas or mesotheliomas after the intrapleural administration of talc (Endo-Capron et al., 1990; Stanton et al., 1977; Wagner et al., 1977). From data from epidemiological studies, the IARC Working Group (1987) concluded that it was possible that carcinogenicity could result from exposure to some specific samples found to be associated with fibrous tremolite. However, epidemiological studies have been updated recently and no evidence of increased risk of lung cancer has been found (Weill et al., 1990). Some authors have examined the association between genital talcum powder exposure and ovarian cancer (Harlow and Weiss, 1989); no appreciable altered risk was

†To whom correspondence should be addressed.

Abbreviations: $\mathrm{FCS}=$ foetal calf serum; $\mathrm{HU}=$ hydroxyurea; $R P M C=($ rat pleural mesothelial cells); $S C E=$ sister chromatid exchange; $T E M=$ transmission electron microscopy; UDS = unscheduled DNA synthesis. observed following exposure to baby powders, which are reported to contain only talc, but an increased risk was associated with the use of talc-containing powders, that is, also containing deodorizing substances or a variety of other free and bound silica (Harlow and Weiss, 1989).

The present experiments were designed to determine whether talc particles of respirable dimensions exerted a genotoxic effect on cultures of rat pleural mesothelial cells (RPMC). Pleural mesothelial cells are an important target for fibrous particles inhaled from our environment and can be used as test models to determine the in vitro effects of particle matter. In addition, talc has been used to overcome pleural effusion (IARC Working Group, 1987). It is therefore of interest to determine the effects of pure talc on RPMC. In previous experiments, we have used RPMC to study the genotoxicity of asbestos fibres. Enhancement of unscheduled DNA synthesis (UDS; Renier et al., 1990) and sister chromatid exchanges (SCE; Achard et al., 1987) have been observed in cultured RPMC after exposure to chrysotile or crocidolite fibres, but not after exposure to a non-carcinogenic sample of attapulgite. Identical tests were applied in this study in order to determine the effects of pure talc.

\section{MATERIALS AND METHODS}

Particles and test compounds. Three samples of European talc provided by Eurotalc (Brussels, Belgium) were studied. One sample each of French talc (no. 7841). Italian talc (no. 5726) and Spanish 
talc (no. 5725) have been tested. Samples contained $90-95 \%$ of talc, the other compounds being chlorite and dolomite. Anatase (a gift from P. Sebastien, Cerchar, France) and attapulgite (from Mormoiron, France) were tested as negative reference particles; Rhodesian chrysotile and crocidolite from the Union Internationale Contre le Cancer (UICC) as positive reference particles. The particles were dispersed in culture medium at a concentration of $560 \mu \mathrm{g} / \mathrm{ml}$ by sonication for $5 \mathrm{~min}(20 \mathrm{KHz}, 3 \mathrm{~W})$. Chemicals used as controls, mitomycin $\mathrm{C}$ (Choay, Paris, France) and $\mathrm{K}_{2} \mathrm{CrO}_{4}$ (Aldrich Chemical Co., Milwaukee, MO, USA), were solubilized in water and in culture medium, respectively.

Transmission electron microscopy (TEM). Particles at a concentration of $100 \mu \mathrm{g} / \mathrm{ml}$ were dispersed in culture medium. An aliquot of the suspension was filtered through a $0.40-\mu \mathrm{M}$ pore size Nuclepore filter. The filters were transferred to electron microscopic grids and dissolved according to the method routinely used in the laboratory (Sébastien et al., 1978). The size of the particles was determined following a systematic scanning of the grid at two magnifications $(\times 33,000$ and $\times 26,000)$.

Cell culture. Rat pleural mesothelial cells (RPMC) were obtained as described elsewhere (Jaurand et al., 1981). Briefly, primary RPMC cultures were obtained by scraping the parietal pleura and allowing the cells to grow in multiwell tissue culture plates. The cultures were maintained in complete medium (i.e. Ham's F10 medium; Flow Laboratories, Irvine, Ayrshire, Scotland) supplemented with 2 mM-L-glutamine (Flow Laboratories), 1 mm-vitamin C (Sigma Chemical Co., St Louis, MO, USA), $10 \mathrm{~mm}$-HEPES (Seromed, Berlin, Germany), 10\% foetal calf serum (FCS; from Boehringer, Mielan, France), $100 \mathrm{U}$ penicillin $\mathrm{ml}$ and $50 \mu \mathrm{g}$ streptomycin $\mathrm{ml}$ (both antibiotica from Flow Laboratories). When the cells reached confluence they were subcultured. From passage 5, RPMC were subcultured approximately every week by standard trypsinization and used between passages 5 and 15 .

Ultrastructural analysis. $24 \mathrm{hr}$ after plating, talc was added to the RPMC in the tissue culture dishes at a concentration of $10 \mu \mathrm{g} / \mathrm{cm}^{2}$. Electron microscopic studies were carried out according to standard methods previously described (Jaurand et al., 1979). The solid compound concentration was expressed as $\mu \mathrm{g} / \mathrm{cm}^{2}$ to take into consideration the particle settling; in these culture conditions, $1 \mu \mathrm{g} / \mathrm{cm}^{2}$ is equivalent to $5 \mu \mathrm{g} / \mathrm{ml}$.

Unscheduled DNA synthesis (UDS). RPMC were cultured in 24-well cluster dishes (Falcon, France); $8 \times 10^{4}$ cells were plated per well in complete medium. Cells reached confluence after 4 days of incubation. The medium of the confluent culture was replaced with RPMI (Flow Laboratories) containing 1\% FCS (Boehringer), $5 \mathrm{~mm}$-hydroxyurea (HU; Sigma) to arrest cells in $\mathrm{G} 1,100 \mathrm{U}$ penicillin $/ \mathrm{ml}$ and $50 \mu \mathrm{g}$ streptomycin $/ \mathrm{ml}$ (both from Flow Laboratories). The cells were incubated for $24 \mathrm{hr}$ in a humidified atmos- phere of $5 \% \mathrm{CO}_{2}$ in air at $37^{\circ} \mathrm{C}$. The cells were then treated for $24 \mathrm{hr}$ with the indicated dose of particles ( $1 \mu \mathrm{g} / \mathrm{cm}^{2}$ is equivalent to $\left.5 \mu \mathrm{g} / \mathrm{ml}\right)$ in $1 \%$ FCS medium containing $5 \mathrm{~mm}-\mathrm{HU}$ and $\left[\right.$ methyl $-{ }^{3} \mathrm{H}$ ] thymidine (Amersham, les Ulis, France) at $4 \mu \mathrm{Ci} / \mathrm{ml}$. The amount of radioactivity incorporated into DNA was determined as described elsewhere (Renier et al., 1990). Six wells were used per treatment. After treatment, cells were washed three times with phosphate buffered saline. Acid-soluble material was removed by rinsing with $10 \%$ cold trichloracetic acid for $10 \mathrm{~min}$ and incubated in a mixture of $0.2 \mathrm{M}-\mathrm{NaOH}$ and $1 \%$ sodium dodecyl sulphate. Aliquots of $200 \mu 1$ were mixed with scintillation fluid (Pico-fluor, Packard) and radioactivity was measured with a Beckman LS 6000SC scintillation counter. Cell DNA content was determined according to West et al. (1985) in separate wells treated with the minerals in the same conditions as described above. Results are expressed as dpm/ $\mu \mathrm{g}$ DNA. All studies were carried out with coded samples.

Sister chromatid exchanges (SCES). RPMC were plated at a density of $2 \times 10^{6}$ cells per $75-\mathrm{cm}^{2}$ flask in RPMI medium supplemented with $10 \%$ FCS. Cells were treated either with test chemicals or with several concentrations of particles plus $3 \mu \mathrm{g}$ bromodeoxyuridine $/ \mathrm{ml} 24 \mathrm{hr}$ after the plating of the culture. In these culture conditions, $1 \mu \mathrm{g} / \mathrm{cm}^{2}$ is equivalent to $7.5 \mu \mathrm{g} / \mathrm{ml}$. The cultures were incubated with the test compound at $37^{\circ} \mathrm{C}$ for $48 \mathrm{hr}$ in the dark. $2 \mathrm{hr}$ before harvesting cells, colchicine (Sigma) at a final concentration of $0.2 \mu \mathrm{g} / \mathrm{ml}$ was added to each culture. Metaphase cells were then detached with $0.25 \%$ trypsin (Eurobio, Paris, France), collected in 15-ml corex tubes and centrifuged at $1500 \mathrm{rpm}$ for $7 \mathrm{~min}$. The supernatant was removed. Cells were treated with $0.075 \mathrm{M}-\mathrm{KCl}$ at $37^{\circ} \mathrm{C}$ for $30 \mathrm{~min}$ before fixation in methanol-glacial acetic acid $(3: 1, \mathrm{v} / \mathrm{v})$. The fixative was changed three times and the last fixation step lasted for one night. The cell suspension was dropped onto an ice-cold slide. Cells were stained by the fluorescence plus Giemsa technique (Perry and Wolff, 1974). 30 metaphases exhibiting 37-42 chromosomes were counted per assay. All studies were carried out with coded samples.

Statistical analysis. The significance of UDS data was evaluated using Student's $t$-test. The number of SCEs observed in treated cell cultures was compared with that in the untreated cultures using the Mann-Whitney test.

\section{RESULTS}

\section{TEM study of particles}

The size distribution of the talc samples is reported in Fig. 1. The characteristics of the talc, anatase, crocidolite and chrysotile particles are reported in Table 1. The mean size of the three talc samples was in the ranking order $5725=7841<5726$. The number 


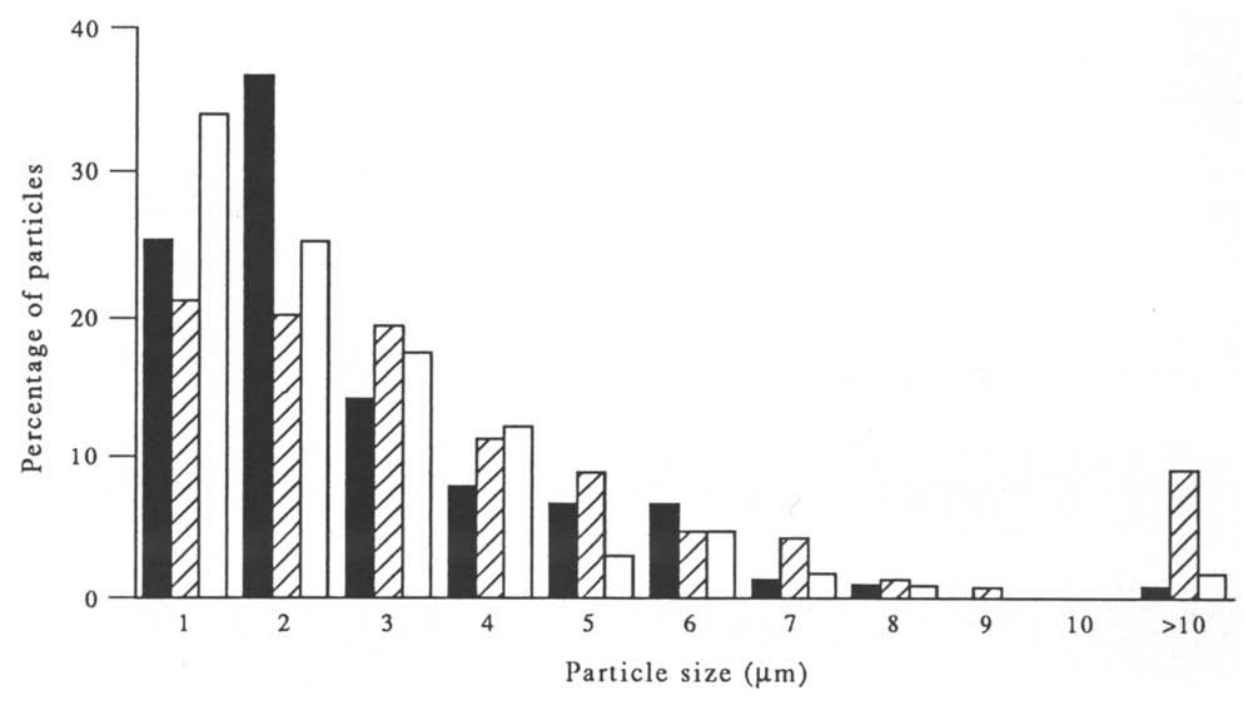

Fig. 1. Size distribution of talc samples no. $5725(\square)$, no. $5726(\square)$ and no. $7841(\square)$.

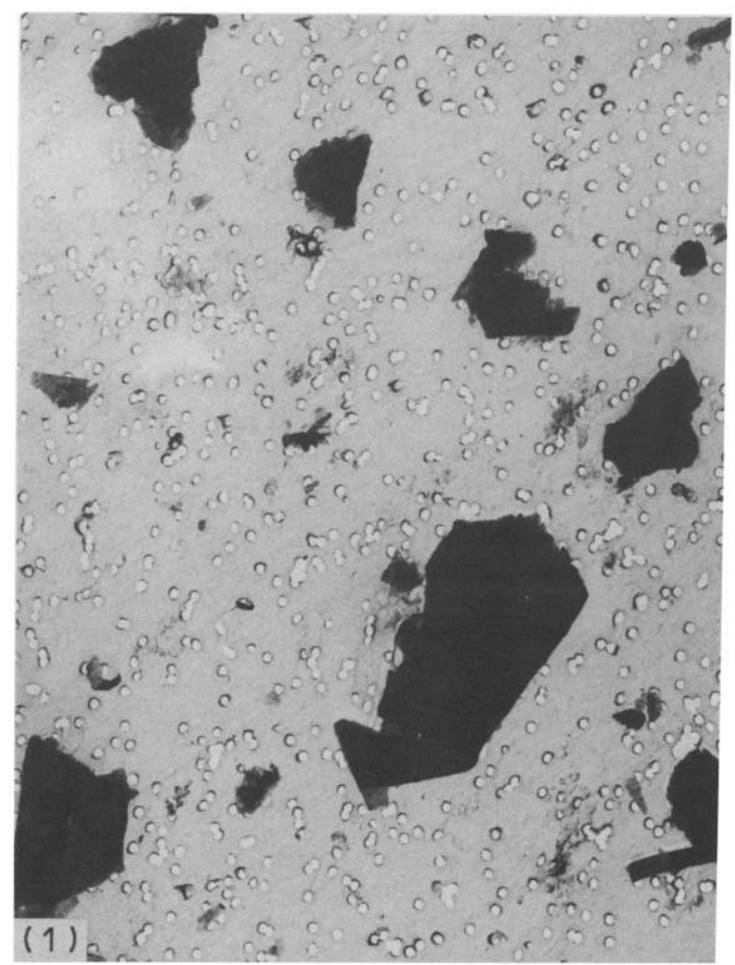

Plate 1. Transmision electron microscopy of talc sample no. $5726(\times 3000)$. 




Plate 2. Rat pleural mesothelial cells, (a) untreated or (b) treated with talc particles (arrows) at $50 \mu \mathrm{g} / \mathrm{cm}^{2}$ for $48 \mathrm{hr}$. Phase contrast microscopy $(\times 115)$.

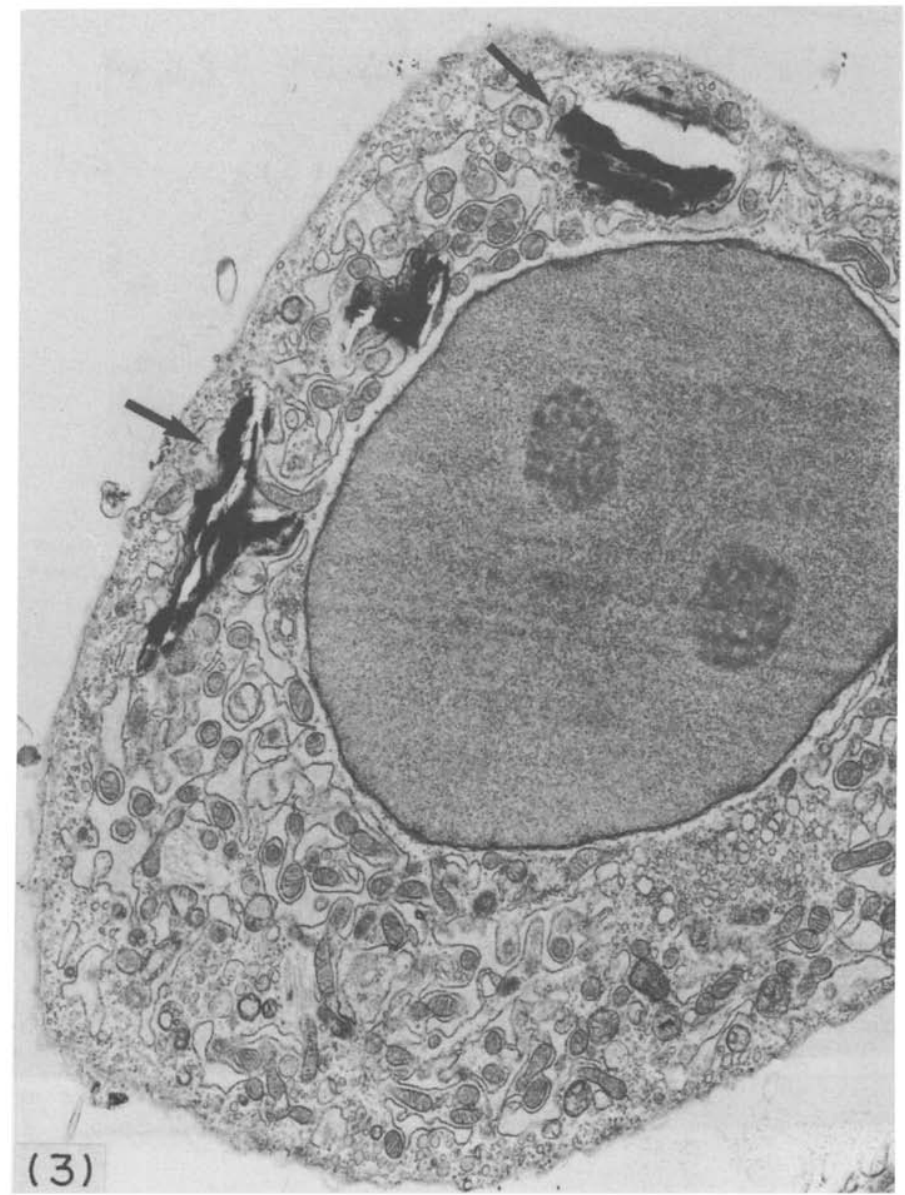

Plate 3. Rat pleural mesothelial cells treated with talc particles (arrows) at $50 \mu \mathrm{g} / \mathrm{cm}^{2}$ for $48 \mathrm{hr}$. Electron microscopy $(\times 6400)$. 
Table 1. Characteristics of the particle samples

\begin{tabular}{lccc}
\hline Sample & $\begin{array}{c}\text { Mean } \\
\text { length } \\
(\mu \mathrm{m})\end{array}$ & $\begin{array}{c}\text { No. of } \\
\text { particles } / \mu \mathrm{g}\end{array}$ & $\begin{array}{c}\text { No. of particles } \\
\text { of length } \\
>4 \mu \mathrm{m} / \mu \mathrm{g}\end{array}$ \\
\hline Talc 5725 & 2.6 & $13.0 \times 10^{4}$ & $2.1 \times 10^{4}$ \\
Talc 5726 & 4.0 & $9.8 \times 10^{4}$ & $2.8 \times 10^{4}$ \\
Talc 7841 & 2.6 & $3.3 \times 10^{4}$ & $0.4 \times 10^{4}$ \\
Anatase & 0.7 & $2.2 \times 10^{9}$ & 0 \\
Crocidolite UICC & 3.1 & $3.0 \times 10^{6}$ & $5.1 \times 10^{5 *}$ \\
Chrysotile UICC & 3.2 & $1.1 \times 10^{7}$ & $2.8 \times 10^{6 *}$ \\
\hline
\end{tabular}

Fibres having a diameter $\leqslant 1.5 \mu \mathrm{m}$.

of particles per unit weight was in the ranking order $5725>5726>7841$. Therefore, the number of particles having a size greater than $4 \mu \mathrm{m}$ is approximately the same in two samples and smallest in sample no. 7841. TEM study showed that none of the three samples of talc contained asbestos fibres (Plate 1). The mean length of crocidolite and chrysotile fibres is between those of talc samples 5725 and 7841 and that of sample 5726 . The number of crocidolite or chrysotile particles having a length greater than $4 \mu \mathrm{m}$ is 20-100 times more than that of talc. Anatase is a very small particle having an average size of less than $1 \mu \mathrm{m}$ with no particle larger than $4 \mu \mathrm{m}$.

\section{Structural and ultrastructural studies}

No structural change has been observed following treatment of RPMC with talc (Plate 2). It appeared that the number of cells was reduced compared with that of untreated cells but no sign of cytolysis was detected. TEM studies have indicated a capacity of RPMC to ingest talc and anatase particles. Plate 3 shows that talc particles were located in the perinuclear region and organelles did not seem changed in comparison with untreated cells.

\section{Unscheduled DNA synthesis (UDS)}

Tables 2 and 3 show the effect of treatment of RPMC with reference particles or talc samples.
Table 3. Unscheduled DNA synthesis in pleural mesothelial cells treated with different talc samples at several doses

\begin{tabular}{|c|c|c|c|c|}
\hline \multirow[b]{2}{*}{$\begin{array}{c}\text { Talc } \\
\text { sample }\end{array}$} & \multirow[b]{2}{*}{$\begin{array}{c}\text { Dose } \\
\left(\mu \mathrm{g} / \mathrm{cm}^{2}\right)\end{array}$} & \multicolumn{3}{|c|}{ Thymidine incorporation (dpm/ $\mu \mathrm{g} \mathrm{DNA})^{*} \dagger$} \\
\hline & & $\begin{array}{c}\text { Experiment } \\
1\end{array}$ & $\begin{array}{c}\text { Experiment } \\
\quad 2 \\
\end{array}$ & $\begin{array}{c}\text { Experiment } \\
3 \\
\end{array}$ \\
\hline No. 5725 & $\begin{array}{r}0 \\
10 \\
20 \\
50\end{array}$ & $\begin{array}{l}1726 \pm 189 \\
1174 \pm 285 \\
1711 \pm 72 \\
1833 \pm 144\end{array}$ & $\begin{array}{l}1299 \pm 100 \\
1310 \pm 120 \\
1289 \pm 189 \\
1232 \pm 38\end{array}$ & $\begin{array}{l}6779 \pm 324 \\
5963 \pm 740 \\
5628 \pm 908 \\
6032 \pm 524\end{array}$ \\
\hline No. 5726 & $\begin{array}{r}0 \\
10 \\
20 \\
50\end{array}$ & $\begin{array}{l}1652 \pm 306 \\
1681 \pm 364 \\
1419 \pm 186 \\
1527 \pm 357\end{array}$ & $\begin{array}{l}1328 \pm 249 \\
1190 \pm 64 \\
1223 \pm 54 \\
1323 \pm 118\end{array}$ & $\begin{array}{l}6708 \pm 357 \\
6049 \pm 666 \\
6086 \pm 534 \\
5405 \pm 420\end{array}$ \\
\hline No. 7841 & $\begin{array}{r}0 \\
10 \\
20 \\
50\end{array}$ & $\begin{array}{l}1532 \pm 23 \\
1321 \pm 40 \\
1293 \pm 12 \\
1271 \pm 36\end{array}$ & $\begin{array}{c}974 \pm 66 \\
1053 \pm 120 \\
928 \pm 60 \\
923 \pm 98\end{array}$ & $\begin{array}{l}6401 \pm 360 \\
6162 \pm 516 \\
6300 \pm 241 \\
6450 \pm 315\end{array}$ \\
\hline
\end{tabular}

*Experiments 1 and 2 were carried out with a specific activity of methyl ${ }^{3} \mathrm{H}$ of $20-30 \mathrm{Ci} / \mathrm{mmol}$; experiment 3 was carried out with a specific activity of $40-60 \mathrm{Ci} / \mathrm{mmol}$.

†Values are means \pm SD for six replicates.

Anatase did not enhance UDS in RPMC. Cells treated with crocidolite at $10 \mu \mathrm{g} / \mathrm{cm}^{2}$ or chrysotile at 4 or $10 \mu \mathrm{g} / \mathrm{cm}^{2}$ always showed a significant enhancement of UDS compared with untreated cells. None of the talc samples tested here enhanced UDS.

\section{Sister chromatid exchanges}

The numbers of SCEs for reference particles, chemicals and talc samples are shown in Table 4. The control particles, attapulgite and anatase, did not induce a significant modification in the number of SCEs. In contrast, increased numbers of SCES were observed when RPMC were treated with the genotoxic chemicals mitomycin $\mathrm{C}$ and $\mathrm{K}_{2} \mathrm{CrO}_{4}$. $\mathrm{A}$ statistically significant enhancement of SCEs was obtained in cells treated with $2 \mathrm{ng}$ mitomycin $\mathrm{C} / \mathrm{ml}$ $(P<0.005)$ or $0.5 \mu \mathrm{g} \mathrm{K}_{2} \mathrm{CrO}_{4} / \mathrm{ml}(P<0.005)$. The mean number of SCEs was significantly increased by chrysotile at $1 \mu \mathrm{g} / \mathrm{cm}^{2}(P<0.005)$ or crocidolite at $2 \mu \mathrm{g} / \mathrm{m}^{2} \quad(P<0.05)$, with significant increases occurring in two out of four and three out of eight experiments with chrysotile and crocidolite,

Table 2. Unscheduled DNA synthesis in pleural mesothelial cells treated with different reference particles at several doses

\begin{tabular}{lcccc}
\hline & & \multicolumn{3}{c}{ Thymidine incorporation $(\mathrm{dpm} / \mu \mathrm{g}$ DNA $) \dagger$} \\
\cline { 3 - 5 } Particle & $\begin{array}{c}\text { Dose } \\
\left(\mu \mathrm{g} / \mathrm{cm}^{2}\right)\end{array}$ & Experiment 1 & Experiment 2 & Experiment 3 \\
\hline Crocidolite $\ddagger$ & 0 & $1299 \pm 100$ & $1327 \pm 57$ & $6086 \pm 299$ \\
& 4 & $1625 \pm 191^{* *}$ & $1425 \pm 926$ & $9572 \pm 463^{* *}$ \\
Chrysotile $\ddagger$ & 10 & $1668 \pm 53^{* * *}$ & $1489 \pm 203^{* *}$ & $8323 \pm 308^{* * * *}$ \\
& 0 & $1495 \pm 106$ & $1362 \pm 117$ & $5632 \pm 326$ \\
& 4 & $1744 \pm 188^{* * *}$ & $1498 \pm 116^{*}$ & $7590 \pm 649^{* * * *}$ \\
Anatase $\$$ & 10 & $1646 \pm 124^{* *}$ & $1598 \pm 64^{* * *}$ & $8157 \pm 341^{* * *}$ \\
& 0 & $1316 \pm 153$ & $6169 \pm 760$ & $6579 \pm 413$ \\
& 2 & $1271 \pm 61$ & $6096 \pm 705$ & $6785 \pm 650$ \\
& 4 & $1380 \pm 276$ & $6535 \pm 565$ & $7214 \pm 301$ \\
& 10 & $1318 \pm 264$ & $6405 \pm 480$ & $7764 \pm 456^{* *}$ \\
\hline
\end{tabular}

†Values are means \pm SD of six replicates and those marked with asterisks differ significantly (Student's $t$-test) from the corresponding value for untreated cells $(* P<0.05 ; * * P<0.01$; $* * * P<0.001)$.

†Experiments 1 and 2 were carried out with a specific activity of methyl ${ }^{3} \mathrm{H}$ of $20-30 \mathrm{Ci} / \mathrm{mmol}$; experiment 3 was carried out with a specific activity of $40-60 \mathrm{Ci} / \mathrm{mmol}$.

\$Experiment 1 was carried out with a specific activity of methyl ${ }^{3} \mathrm{H}$ of $20-30 \mathrm{Ci} / \mathrm{mmol}$; experiments 2 and 3 were carried out with a specific activity of $40-60 \mathrm{Ci} / \mathrm{mmol}$. 
Table 4. SCE induction in RPMC treated with reference particles, chemicals and talc samples

\begin{tabular}{|c|c|c|c|c|}
\hline Treatment & $\begin{array}{l}\text { No. of } \\
\text { experi- } \\
\text { ments }\end{array}$ & $\begin{array}{c}\text { Dose } \\
\left(\mu \mathrm{g} / \mathrm{cm}^{2}\right) \dagger\end{array}$ & $\begin{array}{l}\text { No. of SCEs/ } \\
\text { metaphasef }\end{array}$ & $\begin{array}{c}\text { No. of } \\
\text { significant } \\
\text { experiments/ } \\
\text { no. of } \\
\text { experiments }\end{array}$ \\
\hline Attapulgite & 3 & $\begin{array}{r}0 \\
20\end{array}$ & $\begin{array}{l}17.6 \pm 2.4 \\
19.7 \pm 1.4\end{array}$ & $0 / 3$ \\
\hline Anatase & 9 & $\begin{array}{l}0 \\
2 \\
5\end{array}$ & $\begin{array}{l}14.6 \pm 2.9 \\
12.9 \pm 3.0 \\
13.9 \pm 2.8\end{array}$ & $0 / 4$ \\
\hline Chrysotile & 4 & $\begin{array}{l}0 \\
1\end{array}$ & $\begin{array}{l}15.2 \pm 1.6 \\
20.2 \pm 3.7^{* *}\end{array}$ & $2 / 4$ \\
\hline Crocidolite & 8 & $\begin{array}{l}0 \\
2\end{array}$ & $\begin{array}{l}14.9 \pm 4.6 \\
16.8 \pm 5.0^{*}\end{array}$ & $3 / 8$ \\
\hline Mitomycin C & 8 & $\begin{array}{l}0 \\
2\end{array}$ & $\begin{array}{l}12.6 \pm 1.5 \\
47.0 \pm 12.7^{* *}\end{array}$ & $4 / 4$ \\
\hline $\mathrm{K}_{2} \mathrm{CrO}_{4}$ & 8 & $\begin{array}{r}0 \\
0.5\end{array}$ & $\begin{array}{l}15.4 \pm 3.4 \\
38.6 \pm 4.2^{* *}\end{array}$ & $4 / 4$ \\
\hline Talc no. 5725 & 3 & $\begin{array}{r}0 \\
2 \\
5 \\
10 \\
15\end{array}$ & $\begin{array}{l}12.2 \pm 1.8 \\
12.2 \pm 1.0 \\
11.8 \pm 2.8 \\
11.3 \pm 0.4 \\
12.6+2.4\end{array}$ & $0 / 3$ \\
\hline Talc no. 5726 & 3 & $\begin{array}{r}0 \\
2 \\
5 \\
10 \\
15\end{array}$ & $\begin{array}{r}12.2 \pm 1.8 \\
12.2 \pm 1.8 \\
9.8 \pm 1.0 \\
12.2 \pm 1.8 \\
12.2 \pm 2.3\end{array}$ & $0 / 3$ \\
\hline Talc no. 7841 & 3 & $\begin{array}{r}0 \\
2 \\
5 \\
10 \\
15\end{array}$ & $\begin{array}{l}12.1 \pm 1.1 \\
11.9 \pm 1.1 \\
11.0 \pm 0.8 \\
11.9 \pm 0.7 \\
11.1 \pm 1.3\end{array}$ & $0 / 3$ \\
\hline
\end{tabular}

†xcept mitomycin $\mathrm{C}(\mathrm{ng} / \mathrm{ml})$ and $\mathrm{K}_{2} \mathrm{CrO}_{4}(\mu \mathrm{g} / \mathrm{ml})$.

$\pm V$ alues are means $+\mathrm{SD}$ for the number of experiments shown, and those marked with asterisks differ significantly (Mann-Whitney test) from the corresponding values for untreated cells $\left({ }^{*} P<0.05 ;{ }^{* *} P<0.005\right)$.

respectively. The number of chromosomes per metaphase and SCE frequencies in RPMC exposed to talc samples 5725,5726 and 7841 are shown in detail in Tables 5 and 6. No difference in the number of chromosomes per metaphase in treated cells was observed in comparison with untreated cells. Moreover, treatment with several concentrations, from 2 to $15 \mu \mathrm{g} / \mathrm{cm}^{2}$, did not increase SCE frequency.

Table 5. Number of chromosomes per metaphase in RPMC treated with three talc samples

\begin{tabular}{|c|c|c|c|c|}
\hline \multirow[b]{2}{*}{ Talc sample } & \multirow[b]{2}{*}{$\begin{array}{c}\text { Dose } \\
\left(\mu \mathrm{g} / \mathrm{cm}^{2}\right)\end{array}$} & \multicolumn{3}{|c|}{ No. of chromosomes/metaphase* } \\
\hline & & $\begin{array}{c}\text { Experiment } \\
1\end{array}$ & $\begin{array}{c}\text { Experiment } \\
2\end{array}$ & $\begin{array}{c}\text { Experiment } \\
3\end{array}$ \\
\hline \multirow[t]{5}{*}{ No. 5725} & 0 & $40.1 \pm 2.6$ & $41.0 \pm 1.6$ & $41.2 \pm 1.5$ \\
\hline & 2 & $41.1 \pm 1.6$ & $41.2 \pm 1.1$ & $40.7 \pm 1.5$ \\
\hline & 5 & $40.3 \pm 1.7$ & $41.1 \pm 1.4$ & $41.0 \pm 1.5$ \\
\hline & 10 & $40.8 \pm 1.6$ & $40.8 \pm 1.7$ & $40.7 \pm 1.6$ \\
\hline & 15 & $40.2 \pm 1.7$ & $40.9 \pm 1.6$ & $41.2 \pm 1.8$ \\
\hline \multirow[t]{5}{*}{ No. 5726} & 0 & $40.4 \pm 2.6$ & $41.0 \pm 1.6$ & $41.2 \pm 1.5$ \\
\hline & 2 & $40.3 \pm 2.0$ & $41.1 \pm 1.3$ & $40.9 \pm 1.5$ \\
\hline & 5 & $40.7 \pm 1.6$ & $40.9 \pm 1.4$ & $40.5 \pm 1.9$ \\
\hline & 10 & $40.7 \pm 1.7$ & $40.6 \pm 1.6$ & $40.6 \pm 1.4$ \\
\hline & 15 & $40.5 \pm 1.7$ & ND & $41.1 \pm 1.7$ \\
\hline \multirow[t]{5}{*}{ No. 7841} & 0 & $41.1 \pm 1.3$ & $41.0 \pm 1.6$ & $41.1 \pm 1.4$ \\
\hline & 2 & $40.7 \pm 2.1$ & $41.1 \pm 1.2$ & $41.2 \pm 1.5$ \\
\hline & 5 & $41.2 \pm 1.4$ & $41.0 \pm 1.7$ & $40.9 \pm 1.7$ \\
\hline & 10 & $40.7 \pm 2.0$ & $40.7 \pm 1.8$ & $40.7 \pm 2.0$ \\
\hline & 15 & $40.6 \pm 2.0$ & $40.7 \pm 1.8$ & $41.1 \pm 1.9$ \\
\hline
\end{tabular}

*Mean \pm SD of 30 metaphases.
Table 6. Number of SCEs in RPMC treated with three talc samples No. of SCEs/metaphase*

\begin{tabular}{|c|c|c|c|c|}
\hline \multirow[b]{2}{*}{ Talc sample } & \multirow[b]{2}{*}{$\begin{array}{c}\text { Dose } \\
\left(\mu \mathrm{g} / \mathrm{cm}^{2}\right)\end{array}$} & \\
\hline & & $\begin{array}{c}\text { Experiment } \\
1\end{array}$ & $\begin{array}{c}\text { Experiment } \\
2\end{array}$ & $\begin{array}{c}\text { Experiment } \\
3\end{array}$ \\
\hline \multirow[t]{5}{*}{ No. 5725} & 0 & $10.1 \pm 3.5$ & $13.3 \pm 5.7$ & $13.2 \pm 5.8$ \\
\hline & 2 & $11.4 \pm 3.5$ & $11.8 \pm 4.1$ & $13.3 \pm 4.9$ \\
\hline & 5 & $9.0 \pm 3.6$ & $11.6 \pm 3.9$ & $14.7 \pm 6.9$ \\
\hline & 10 & $11.4 \pm 3.7$ & $10.9 \pm 3.5$ & $11.6 \pm 5.6$ \\
\hline & 15 & $11.6 \pm 3.5$ & $10.9 \pm 3.2$ & $15.3 \pm 5.4$ \\
\hline \multirow[t]{5}{*}{ No. 5726} & 0 & $10.1 \pm 3.5$ & $13.3 \pm 5.7$ & $13.2 \pm 5.8$ \\
\hline & 2 & $11.0 \pm 2.9$ & $11.4 \pm 4.1$ & $14.3 \pm 5.0$ \\
\hline & 5 & $9.3 \pm 3.0$ & $11.0 \pm 3.6$ & $9.2 \pm 6.2$ \\
\hline & 10 & $10.6 \pm 3.4$ & $11.9 \pm 3.6$ & $14.1 \pm 5.0$ \\
\hline & 15 & $10.5 \pm 2.8$ & ND & $13.8 \pm 5.4$ \\
\hline \multirow[t]{5}{*}{ No. 7841} & 0 & $12.0 \pm 4.3$ & $13.3 \pm 5.7$ & $11.1 \pm 4.4$ \\
\hline & 2 & $10.6 \pm 3.0$ & $12.2 \pm 3.8$ & $12.9 \pm 4.9$ \\
\hline & 5 & $10.8 \pm 4.9$ & $10.3 \pm 3.6$ & $12.0 \pm 4.0$ \\
\hline & 10 & $12.1 \pm 5.4$ & $11.2 \pm 4.5$ & $12.5 \pm 6.2$ \\
\hline & 15 & $11.0 \pm 3.8$ & $9.9 \pm 3.7$ & $12.5 \pm 3.9$ \\
\hline
\end{tabular}

$*$ Mean \pm SD of 30 metaphases.

\section{DISCUSSION}

In the in vitro studies reported here we investigated the effects of talc in genotoxic assays. We observed that the three talc samples did not increase UDS or SCEs, or produce aneuploidy in RPMC. In contrast, chrysotile and crocidolite fibres consistently enhanced UDS, as well as increasing SCEs in some of the experiments. This is in agreement with previous observations in our laboratory (Achard et al., 1987; Renier et al., 1990). SCE enhancement was also obtained after treatment of RPMC with mitomycin C and $\mathrm{K}_{2} \mathrm{CrO}_{4}$, agents previously known to induce $\mathrm{SCE}$ (Darroudi and Natarajan, 1989; Kato and Shimada, 1975; Levis and Bianchi, 1982; Littlefield et al., 1979; Perry, 1980). The negative reference particle, anatase, did not increase either UDS or the frequency of SCEs in comparison with untreated RPMC.

In spite of the fact that talc is a magnesium silicate, as are chrysotile fibres, the in vitro responses of the two particles are different. As far as the mechanisms of genotoxicity of particles are concerned, several factors might account for the different responses, in particular phagocytosis, granulometry and the shape of the particles. Several questions can be addressed.

First, is the lack of genotoxic action of talc due to the absence of phagocytosis? Phagocytosis seems to play an important role in the genotoxic effect of particles, because fibres phagocytosed could interact with the mitotic spindle (Hesterberg and Barrett, 1985) or chromosomes (Wang et al., 1987). This may then induce aneuploidy by chromosomal missegregation (Hesterberg and Barrett, 1985; Palekar et al., 1987). Our TEM study showed that RPMC can ingest talc particles. This cellular process has been also observed with chrysotile and crocidolite asbestos fibres (Jaurand et al., 1979 and 1983). Despite phagocytosis, talc did not induce aneuploidy since the number of chromosomes per metaphase in talctreated cells was not different from that in untreated cells (Table 5). Therefore, the lack of chromosomal 
damage might be related to different mechanical or physicochemical properties of talc in comparison with mineral fibres.

Secondly, is the absence of genotoxic action due to the size of the talc particles? From the data reported in the literature, the carcinogenic potency of particulate matter seems to be dependent on both shape and dimension. For example, Stanton et al. (1981) have reported that after intrapleural inoculation into the rat, the frequency of pleural sarcomas was dependent on the number of fibres less than $0.25 \mu \mathrm{m}$ in diameter and more than $8 \mu \mathrm{m}$ in length. Moreover, an in vitro assay has shown that thick glass fibres were more efficient than thin fibres, on a per number basis, in transforming Syrian hamster embryo cells. In addition, no transformation was obtained when the fibre length was reduced to $0.95 \mu \mathrm{m}$ (Hesterberg and Barrett, 1984). In contrast to asbestos fibres, talc does not have a fibrous shape, but rather a polygonal form. Fibre samples containing long fibres can be deposited in the airways because of their small diameter, whereas respirable talc particles with a diameter higher than $5 \mu \mathrm{m}$ do not reach the deep lung. The absence of an in vivo effect of talc might also be due to the small size of the particles. The size and number of particles per unit weight are different in the three talc samples. Granulometric study of the talc samples showed that the mean size was in the ranking order $5725=7841<5726$ and of the same order as that of asbestos fibres. However, the number of long ( $>4 \mu \mathrm{m}$ ) particles is much higher in asbestos samples than in the talc samples used here.

The three talc samples did not enhance UDS or induce SCEs in comparison with untreated RPMC. This is in contrast to the results with asbestos, especially with regard to the UDS assay in which a significant response was observed with both types of asbestos fibres. The SCE results seem less convincing; in effect, no consistent positive enhancement of SCEs was found with crocidolite, thus lessening the significance of the negative response obtained with talc. However, our observations are in agreement with in vivo data reported by Stanton et al. (1981) and with our previous results obtained with sample no. 7841 , which showed that talc did not produce tumours following intrapleural inoculation (Endo-Capron et al., 1990), as well as with in vitro results that showed that talc did not induce chromosomal effects in mammalian cells in vivo and in vitro (IARC Working Group, 1987).

Acknowledgements - This work has been supported by INSERM funds and Eurotalc subvention.

\section{REFERENCES}

Achard S., Perderiset M. and Jaurand M. C. (1987) Sister chromatid exchanges in rat pleural mesothelial cells treated with crocidolite, attapulgite or benzo 3-7 pyrene. British Journal of Industrial Medicine 44, 281-283.
Darroudi F. and Natarajan A. T. (1989) Cytogenetical characterization of chinese hamster ovary $\mathrm{X}$-ray-sensitive mutant cells Xrs 5 and Xrs 6. III Induction of cell killing chromosomal aberrations and sister chromatid exchanges by bleomycin, mono- and bi-functional alkylating agents. Mutation Research 212, 123-125

Endo-Capron S., Fleury-Feith J., Nebut M., De Neef R. and Jaurand M. C. (1990) Some in vivo and in vitro studies carried out with talc samples. In Health Related Effects of Phyllosilicates. Edited by J. Bignon. NATO ASI series, Serie G: Ecological sciences, Vol. G21. pp. 367-375. Springer-Verlag, Berlin.

Harlow B. L. and Weiss N. S. (1989) A case-control study of borderline ovarian tumors: the influence of perineal exposure to talc. American Journal of Epidemiology 130, 390-394.

Hesterberg T. W. and Barrett J. C. (1984) Dependence of asbestos and mineral dust-induced transformation of mammalian cells in culture of fiber dimension. Cancer Research 44, 2170-2180.

Hesterberg T. W. and Barrett J. C. (1985) Induction by asbestos fibres of anaphase abnormalities: mechanism of aneuploidy induction and possibly carcinogenesis. Carcinogenesis 6, 473-475.

IARC Working Group (1987) IARC Monographs on the Evaluation of the Carcinogenic Risk of Chemicals to Humans. Vol. 42. Silica and some silicates. pp. 185-224. International Agency for Research on Cancer, Lyon.

Jaurand M. C., Bastie-Sigeac I., Bignon J. and Stoebner P. (1983) Effect of chrysotile and crocidolite on the morphology and growth of rat pleural mesothelial cells. Environmental Research 30, 255-269.

Jaurand M. C., Bernaudin J. F., Renier A., Kaplan H. and Bignon J. (1981) Rat pleural mesothelial cells in culture. In Vitro 17, 98-105.

Jaurand M. C., Kaplan H., Thiollet J., Pinchon M. C., Bernaudin J. F. and Bignon J. (1979) Phagocytosis of chrysotile fibers by pleural mesothelial cells in culture. American Journal of Pathology 94, 529-538.

Kato H. and Shimada H. (1975) Sister chromatid exchanges induced by mitomycin $\mathrm{C}$ : a new method of detecting DNA damage at chromosome level. Mutation Research 28, 459-464.

Levis A. G. and Bianchi V. (1982) Mutagenic and cytogenetic effects of chromium compounds. In Biological and Environmental Aspects of Chromium. Edited by Langard. pp. 171-209. Elsevier Biomedical Press.

Littlefield L. G., Colyer S. P., Sayer A. and Dufrain R. J. (1979) Sister-chromatid exchanges in human lymphocytes exposed during G0 to four classes of DNA damaging chemicals. Mutation Research 67, 259-269.

Palekar L. D., Eyre J. F., Most B. M. and Coffin D. L. (1987) Metaphase and anaphase analysis of V79 cells exposed to erionite, UICC chrysotile and UICC crocidolite. Carcinogenesis 8, 553-560.

Perry P. E. Chemical mutagens and sister chromatid exchange. (1980) In Chemical Mutagens, Principles and Methods for their Detection. Vol. 6. Edited by F. J. de Serres and A. Hollaender. pp. 1-39. Plenum Press, New York.

Perry P. and Wolff S. (1974) New Giemsa method for the differential staining of sister chromatids. Nature, London 251, 156-158.

Renier A., Lévy F., Pillière F. and Jaurand M. C. (1990) Unscheduled DNA synthesis in rat pleural mesothelial cells treated with mineral fibres. Mutation Research 241, 361-367.

Sébastien P., Billon M. A., Janson X., Bonnaud G. and Bignon J. (1978) Utilisation du microscope électronique à transmission (MET) pour la mesure des contaminations par l'amiante. Archives des Maladies Professionnelles 39, 229-248. 
Stanton M. F., Layard M., Tegeris A., Miller E., May M. and Kent E. (1977) Carcinogenicity of fibrous glass: pleural response in the rat in relation to fiber dimension. Journal of the National Cancer Institute 58, 587-603.

Stanton M. F., Layard M., Tegeris A., Miller E., May M., Morgan E. and Smith A. (1981) Relation of particle dimension to carcinogenicity in amphibole asbestos and other fibrous minerals. Journal of the National Cancer Institute 67, 965-975.

Wagner J. C., Berry G., Cooke T. J., Hill R. J., Pooley F. D. and Skidmore J. W. (1977) Animal experiments with talc. In Inhaled Particles IV. Edited by W. H. Walton and B. McGovern. Part 2, pp. 647-654. Pergamon Press, Oxford.
Wang N. S., Jaurand M. C., Magne L., Kheuang L., Pinchon M. C. and Bignon J. (1987) The interaction between asbestos fibres and metaphase chromosomes of rat pleural mesothelial cells in culture. American Journal of Pathology 126, 343-349.

Weill H., Abraham J. L., Balmes J. R., Case B., Churg A. M., Hughes J., Schenker M. and Sébastien P. (1990) Health effects of tremolite. American Review of Respiratory Diseases 142, 1453-1458.

West D. C., Satter A. and Kumar S. (1985) A simplified in situ solubilization procedure for the determination of DNA and cell number in tissue cultured mammalian cells. Analytical Biochemistry 147, 289-295. 